3 miles of the mouth of the Flint River. Two of them are dated July 9, another July 8, the fourth, August 8 . This last specimen is peculiar in having only the front wings darkened apically, though quite mature. The others are all of the race hudsonicum, although one of them approaches the race aquabile slightly in having a little less black on the hind wings.

I have also a series from several parts of Algonquin Park, Ont., which is on the edge of the Canadian Zone. Some of these specimens are typical hudsonicum, and on the whole they are quite similar to the Kenogami River specimens. Another series, taken at Kitchener, Ont., (formerly Berlin), by W. J. Fraser have, on an average, slightly less black on the apices of the wings than the Algonquin Park specimens. Some of these are typical cequabile except that the black area of the front wings is perhaps a little smaller, while others are nearer hudsonicum and cannot be distinguished from Algonquin Park specimens.

IIudsonicum tends to be a larger, stouter race than aquabile.

E. M. WALKER.

NEW NEARCTIC CRANE-FLIES (TIPULIDA, DIPTERA). PART VI.

BY CHARLES P. ALEXANDER, LAWRENCE, KANS.

(Continued from Page 386.)

Tipula kansensis, new species.

Coloration pale brownish yellow; the mesonotal præscutum with five narrow, dark brown lines; antennal flagellum dark brown; wings with a white and brown picture on a pale brownish gray ground; male hypopygium with the ninth tergite small, deeply impressed medially to form two tumid halves; ninth pleurite produced into a flattened, chitinized lobe that is truncated apically; two pendulous, fleshy lobes in the notch of the ninth sternite.

Male.-Length $17 \mathrm{~mm}$.; wing $15.3 \mathrm{~mm}$.

Frontal prolongation of the head long, grayish brown; nasus indistinct; palpi with the three basal segments brownish yellow, the terminal segment dark brown. Antennæ rather short, the first three segments brownish yellow, the flagellum dark brown; the basal enlargements of the segments a little darker. Head grayish brown, with a distinct impressed median line.

Mesonotal præscutum brownish yellow, the usual stripes December, 1818 
represented only by dark brown margins, there being five such narrow lines, of which the lateral ones are broadest; remainder of the mesonotum grayish yellow, with numerous black setigerous punctures. Pleura yellow, sparsely gray pruinose. Halteres short, yellow, the knob, except at the tip, dark brown. Legs with the coxæ and trochanters yellow; femora dull yellow, the tips indistinctly brown; tibix brownish yellow; tarsi similar, the terminal segments darker. Wings mottled with brownish gray and whitish; costal cell yellow; subcostal cell similar but even more intense; stigma yellowish brown; membrane brownish gray, with darker spots at the origin of the sector and along the cord; large whitish areas along the cord extending from $R$ through cell $C u^{1}$ to the wing margin; a pale area beyond the stigma in cell $2 n d R^{1}$ and the base of $R^{2}$; cell $M^{1}$ largely pale; two large, pale areas in the first anal cell. Venation: $R^{2}$ long, a little longer than the petiole of cell $M^{1}$; cell 1 st $M^{2}$ small, the punctiform $m$-cu inserted at about one-third to one-fourth its length.

Abdominal tergites brownish yellow, becoming darker near the hypopygium; an indistinct, interrupted, brown sublateral stripe; basal segments broadly ringed with silvery; sternites brownish yellow. Male hypopygium rather large. Ninth tergite small, deeply impressed dorso-medially to form two tumid halves; caudal margin flattened, with a deep, V-shaped median notch, the adjacent lobes subacute, reddish, each with a small, U-shaped lateral notch. Ninth pleurite incomplete, the pleural suture deep, the dorsal posterior margin of the pleurite produced dorsad into a flattened, chitinized margin that is truncated apically; outer pleural appendage small, slender, cylindrical. Dorsal inner angle of the ninth sternite with two pendulous, fleshy lobes hanging in the notch of the sternite, these tumid and clothed with abundant long, pale hairs; eighth sternite large, the caudal margin almost straight medially, with a broad fringe of long yellow hairs; the lateral lobes produced.

Habitat.-Kansas.

Holotype.- $\sigma^{7}$, Lawrence, Douglas County, Kansas, June 4, 1918.

Tipula alaska, new species.

Antennæ with the flagellum uniformly pale brown; meso- 
notum dull yellow, the prascutum with three brown stripes; wings subhyaline or with a very indistinct pattern; abdomen yellow, trivittate with reddish brown; male hypopygium with the ninth tergite large, flattened, narrowed posteriorly and with a very deep median notch.

Male.-Length $17 \mathrm{~mm}$.; wing $17.7 \mathrm{~mm}$.

Female.-Length $20 \mathrm{~mm}$; wing $17.5 \mathrm{~mm}$.

Frontal prolongation of the head moderately elongated, dull brownish yellow, the nasus very small. Antennæ of the male moderately elongated, the scape yellow, the flagellar segments uniformly pale brown; basal swelling of the flagellar segments not conspicuous. Head brownish yellow.

Thoracic dorsum dull yellow, the mesonotal præscutum with three dark brown stripes, the median one a little paler and bisected behind, the lateral stripes continued backward on to the scutal lobes; scutellum dark brown, more yellowish laterally; postnotum dull yellow medially, brown on the sides; a delicate capillary brown line extends from the prascutum backward to the base of the abdomen. Pleura dull yellow, the mesosternum and the mesepisternites brown. Halteres pale, the knobs, except the tips, paler. Legs with the coxæ dull yellow, the cephalic face of each more brownish; trochanters dull yellow; femora yellow, the tips broadly dark brown; tibiæ and tarsi similar, the tips of the individual segments narrowly darker. Wings grayish, the stigma more yellowish brown outwardly; a broad obliterative streak along the cord continued into the base of cell $M^{4}$. Venation: basal deflection of $R^{4+5}$ short or punctiform; basal deflection of $C u^{1}$ from one-third to one-fourth the length of cell 1 st $M^{2}$.

Abdomen dull yellow, the segments narrowly ringed caudally with silvery; tergites beyond the base with a narrow, indistinct, reddish-brown stripe that is interrupted at the posterior margins of the segments; lateral margins of the segments with a conspicuous triangular reddish-brown blotch; basal sternites yellowish, terminal sternites darker coloured. Male hypopygium moderately enlarged. Ninth tergite large, flattened, narrowed posteriorly, with a very deep median notch, the lobes formed being elongate, flattened, a little divergent, the tips subacute; the tergite is dark brown on each side of the base, the apex yellowish. Ninth pleurite 
incomplete, the suture well indicated beneath, the posterior margin of the pleurite produced caudad into a slender point; ventrad of the pleurite is a large, greenish, fleshy lobe; outer pleural appendage pale, rather small, club-shaped, the base constricted, the outer face with long, scattered hairs. What appears to be the gonapophyses of the penis-guard project caudad as two acute chitinized points. Eighth sternite rather large, the caudal margin pale, the median area flattened, transverse, finely fringed with reddish hairs, the lateral angles produced caudad and provided with a few strong, decussate bristles and a few smaller hairs. Female ovipositor with all the valves slender, subequal in length, the tips of the dorsal valves bluntly rounded.

Habitat.-Alaska. 1910.

Holotype.- $\sigma^{7}$, head of the Tsirku R., Alaska, July-August,

Allotype.-o, with the type.

Tipula flavibasis, new species.

Size small (wing under $14 \mathrm{~mm}$.); antennæ of the male elongated, bicolorous, the basal enlargement of each segment yellow, the remainder black; mesonotum yellowish brown without distinct stripes; wings with a strong gray tinge.

Male.-Length 11.5-12 mm.; wing $12.2-12.7 \mathrm{~mm}$.; antennæ about $4.5-5 \mathrm{~mm}$.

Female.-Length $16 \mathrm{~mm}$; wing $12.3-13.3 \mathrm{~mm}$.

Frontal prolongation of the head yellowish brown; nasus not distinct. Palpi with the basal segments brown, pale at the joints, the terminal segments more yellowish. Antennæ of the male elongated, the scape dull yellow, the first flagellar segment pale yellowish brown on the basal half, dark brownish black on the apical half; remaining flagellar segments with the basal swelling yellow, the pedicel black. Head gray, the occiput more yellowish the inner margin of the eyes narrowly pale gray.

Mesonotum yellowish brown, the usual stripes poorly indicated Pleura yellow with a very sparse white bloom. Halteres pale, the knobs brown. Legs with the coxæ and trochanters light yellow, femora yellow, the tips narrowly dark brown; tibiæ similar, the tips indistinctly darker; tarsi brownish yellow, the apices of the segments slightly darkened. Wings with a strong gray tinge, the 
costal and subcostal cells yellow; stigma dark brown; a brown mark at the arculus; veins dark brown; obliterative streak broad, extending into the base of cell $M^{4}$.

Abdomen with the tergites yellowish; a broad, dark brown median stripe that is interrupted at the posterior margins of the segments; a narrower sublateral stripe; sternites yellow. Male hypopygium moderately enlarged. Ninth tergite large, the caudal margin shiny with a very deep notch at the base of which is a small, acute median tooth; lateral angles prominent, flattened, subacute and slightly divergent. at their apices. Ninth pleurite complete or practically so; outer pleural appendage small, cylindrical, covered with long, coarse hairs; inner pleural appendage complex, produced posteriorly into a pale, flattened, truncated lobe that is covered with abundant pale hairs, the anterior arm heavily chitinized, the tip bifid and jutting into the notch of the tergite. Ninth sternite with two pendulous lobes hanging in the notch, these lobes narrowed toward their outer ends. Eighth sternite with the posterior margin concave, the median portion with a dense, transverse fringe of long, yellow hairs, near each lateral angle with about two powerful decussate bristles. Penisguard very elongate, the tip split into two hair-like points.

The female is similar to the male; antennæ short; abdomen with the dorso-median stripe lacking, the posterior margins of the segments broadly ringed with pale; ovipositor with the valves acute, compressed, the tergal valves longest, blackened at their tips.

Habitat.-Kansas.

Holotype. $0^{7}$, Lawrence, Douglas Co., Kans., July 1, 1918.

Allotype.- o , with the type.

Paratopotypes.-75 $0^{7}$ 's $\%$ 's, June 28-July 3, 1918.

In the peculiar antennæ, this interesting species agrees with T. tephrocephala $\mathrm{Lw}$, but in all other respects is a very different fly.

Tipula flavo-umbrosa, new spécies.

Male.--Length $22 \mathrm{~mm}$; wing $21.5-22 \mathrm{~mm}$.

Female-Length 21-22 mm.; wing $18 \mathrm{~mm}$.

Very similar to Tipula umbrosa Lw. (inermis Doane) but larger than that species and much more yellow throughout. The 
antennæ are more clearly bicolorous apically. Præscutal stripes orange instead of dark brown, the median pair narrow, widely divided by the ground-colour. Wings strongly tinged with yellow before the cord, the costal cells yellow instead of brown. Abdomen more yellowish, especially laterally. Male hypopygium with the median area of the eighth sternite with two broadly triangular teeth, the notch between them V-shaped or narrowly U-shaped. The female is similar to the male but somewhat smaller.

Habitat.-Central United States.

Holotype.-- $\sigma^{7}$, Lawrence, Douglas Co., Kansas, June 6, 1918. Allotype.-o, with the type (M. M. Alexander).

Paratopotypes.- Several or 9 .

I have examined the type of umbrosa at Cambridge, and have seen paratypes of inermis, and they both refer to the smaller darkcoloured species of this group. It is possible that still other species remain to be separated from this complex.

\title{
SOME NEW OR SCARCE COLEOPTERA FROM WESTERN AND SOUTHERN FLORIDA.
}

\author{
BY W. S. BLATCHLEY, INDIANAPOLIS, INDIANA.
}

Between December 1, 1917, and April 1, 1918, the writer was in Florida and collected Coleoptera and Orthoptera for much of the time. The most of the collecting was done about Dunedin, ${ }^{*}$ a town in Pinellas County on the west coast, but in tate February and early March a trip was taken to the Lake Okeechobee region, during which several days' collecting was done at each of the following places: Lakeland, Ft. Myers, LaBelle, Moore Haven** and Okeechobee City. One day was also spent on the east shore of Lake Okeechobee at the point where the Palm Beach Canal leaves the lake. The species of Coleoptera herein noted, on account of their apparent scarcity in the State, or which are regarded as undescribed forms, were for the most part taken during the winter at some one or more of the places above mentioned.

* See Canadian Entomologist, 1917, 137.

* This is a new town on the west side of Lake Okeechobee, at the point where the Caloosahatchie River formerly emerged from the lake. A large area of the old lake area southeast of the town has been drained and is now under cultivation.

December, 1918 